\title{
Ideologies Behind the Halal Tourism Sector
}

Saortua Marbun

Sekolah Tinggi Ilmu Ekonomi Triatma Mulya

Jalan Kubu Gunung Tegal Jaya Dalung Kuta Utara Badung Bali 80361 Indonesia

e-mail: saortua.marbun@triatma-mapindo.ac.id

\begin{abstract}
A quick scan of the available literature on the subject of halal tourism reveals that many scholars and laypersons alike misconceive this concept. Whereas some suggest that halal tourism occurs whenever a Muslim individual travels somewhere, others retort that only pilgrimages by Muslim travelers regarded as halal tourism. More careful research of the literature shows that the truth is somewhere in between, as none of the above definitions is correct. Overall, it is this lack of clarity that has prompted an additional inquiry into the essence of halal tourism. This essay is a modest academic endeavor to ascertain what halal tourism is and what ideologies lie at its foundation. To answer these questions, the author employs the literature review research methodology, scrutinizing number sources. Ultimately, this essay has established that halal tourism not confined to religious pilgrimages alone. Indeed, halal tourism occurs whenever a Muslim individual travels for religion, business or leisure and uses only those services and facilities that conform to the teachings of Islam.
\end{abstract}

Keywords: tourism, travel, halal tourism, Islamic tourism, Islamic teachings, Sharia.

\section{Introduction}

Just half a century ago, travel was an undeniable synonym for adventure and exploration. In the popular imagination, any widely traveled individual associated with an aura of mysteriousness. Today, by contrast, travel and tourism have become more common and mundane, as ever more significant numbers of people flock to both domestic and foreign 
destinations for business and recreation or to simply quench their wanderlust. The travel industry has evolved correspondingly, learning to cater to the specific needs of different categories of tourists and travelers. Some of the most common and clearly defined subcategories of tourism that have developed in recent decades include green tourism, religious tourism, sports tourism, shopping tourism, wellness tourism, package tours and pardon the obscenity - even sex tourism. Halal tourism, for its part, is yet another burgeoning subcategory of tourism. Despite its growing dimensions, the concept of halal tourism is often misunderstood and misrepresented in popular media.

Given the problem, this essay seeks to understand the concept of halal tourism better. By extension, the piece attempts to ascertain the ideologies behind this subcategory of tourism. In other words, the essay examines the relationships between halal tourism on the one hand and religion, management, economics and politics on the other. By these findings, the article seeks to make an informed assessment if the halal tourism sector is capable of withstanding competition from conventional tourism. The overarching argument is, therefore, straightforward: Halal tourism is designed to enable pious Muslim tourists to pray towards Mecca, use gender-segregated facilities and otherwise abide by the Quranic teachings on vacation without raising eyebrows or causing other discomforts. Although evidence suggests that some Muslims are embracing a capitalist consumer culture, it is reasonable to opine that halal tourism will assume even greater dimensions in the future.

\section{Methodology}

Considering the constraints of this paper, no primary data were collected to conduct a more robust and comprehensive research project. This limitation, however, does not vitiate the significance of the present essay. Nor does it significantly diminish the contribution of the present article to the relevant academic scholarship on the subject of halal tourism. The most 
significant value of this article is that it scrutinizes pertinent academic literature to collect evidence. More specifically, it distills and synthesizes common threads from the reviewed scholarship. Many sources were a review for this article. Although several of the used sources are somewhat outdated, they nonetheless provide valuable insights into the topic. The majority of the sources are, however, more up-to-date. Likewise, while some articles from mass media made their way into this essay, the emphasis was on credible sources like articles from peer-reviewed scholarly journals, books published by authoritative publishing houses, articles from reliable newspapers and official reports. To locate these sources, the author of this essay scanned online databases with such keywords as "halal tourism," "halal destination," "Muslim friendly tourism," etc.

\section{Results}

Simply put, halal tourism refers to a tourist sector that caters to the needs and requirements of Muslim travelers. To get a more elaborate idea of what halal tourism is, however, it is essential to cite and deconstruct more detailed definitions adduced by competent organizations and individual commentators. Specialists at the Organization of Islamic Cooperation, for example, contend that halal tourism occurs when Muslim travelers visit predominantly Muslim destinations, with religious motivations representing the main reason why they choose these specific destinations ("Strategic roadmap for the development of Islamic tourism in OIC member countries" 2017). It is crucial to acknowledge that halal tourism is a broader concept and it can occur even in those countries where Islam is not the dominant faith. In the same vein, halal tourism can happen in situations when spiritual fulfillment or pilgrimage is not the main reasons why Muslim travelers come to a particular destination. Henderson (2009) concurs with this judgment, further adding that Muslim tourists who travel abroad for recreation rather than the religion but conform to Islamic 
teachings at the same time are mainly participating in halal tourism. El-Gohary, Edwards, and Eid (2017), too, believe that it is counterproductive and counterintuitive to limit halal tourism only to pilgrimages dogmatically. Other researchers, including Al-Hamarneh (2008), go even further, surmising that any trip taken by a Muslim tourist is part of halal tourism by default. This approach is, however, ineffective, for it blurs the real boundaries of halal tourism. With the same luck, any trip taken by a Christian could be branding as Christian tourism. But this branding would be meaningless, failing to add any novelty to the field of tourism studies.

It should be noted, in an important aside, that the well-established kosher tourism is not solely about demographics. It is more about accommodating the needs of a particular demographic group. As seen from the definitions of Henderson and El-Gohary, Edwards and Eid, halal tourism is even more concrete and specific concept. Overall, what this passage serves to show is that halal tourism requires adherence to Islamic rules of propriety by Muslim travelers for their trips to be duly considered as representing halal tourism.

The discussion above already alludes to the idea that halal tourism is integral to religion. Despite the commonly regarded belief to the contrary, moreover, that religion is the mainstay of halal tourism, its lynchpin, its cornerstone. Nathalie Bourgeois (2016) addresses what some commentators - those in the west, mainly - see as the incongruence between tourism and Islam:

To many non-Muslim Westerners, the expression "Islamic tourism" might seem an oxymoron, an improbable association between a strict religion and the western idea of carefree idleness in exotic locations. The Prophet himself preached Muslims to go and discover the world: "Travel through the land and observe how He began creation," says the Quran (p. 1). 
For Muslim travelers, therefore, halal tourism implies the necessity to organize their trips under the beliefs and practices of Islam. For travel companies, hotels and other service providers, halal tourism suggests the need to offer only such facilities that propagate Islamic teachings. Although no codified standards of halal tourism exist, the consulted authors explain that service providers involved in this industry tend to provide separate swimming pools for males and females, serve halal food and do not serve alcohol, announce prayer timings, have Qurans readily available, and even broadcast religious content as part of entertainment (Shirazi, 2016; Raj \& Griffin, 2017). Hashim, Shariff, Mahamood, and Bhari (2018) weigh in to suggest that even charter flights booked for Muslim travelers frequently geared toward Muslim standards. In doing so, these service providers are driven by either the desire to attract more Muslim travelers or by their religious consciousness. One or the other way, it is understood that religious ideologies are ubiquitous in the halal tourism sector.

Halal tourism has political implications too. It could say in the very least that halal tourism promotes Islamic solidarity (Reiter, 2008; Kozak \& Kozak, 2015). This subcategory of tourism could also potentially have an impact on Islamic nationalism (US Congress, 2009). Pinpointing the exact political effects of halal tourism goes beyond the purposes of this essay. It is instead more important to focus on the economic ideologies undergirding the halal tourism sector. It is imperative to make a reservation in this context that halal tourism is not merely about religion, politics, and thinking. Like any other business enterprise, it is also about income. On the face of things, it seems illogical from the standpoint of economics and fiscal integrity that travel service providers would deliberately limit their services to Muslim individuals, thereby eliminating a vast swath of non-Muslim tourists. Frequently, however, it is just a matter of perspective. If travel service providers reason that Muslim tourists are a more profitable market for them, the consulted authors agree, these service providers can make a volte-face in favor of this market at the expense of the less lucrative non-Muslim 
market (Demir \& Toprak, 2004; Adas, 2006; Eddahar, 2016). Drawing on the example of Turkey, Elaziz and Kurt (2017) explain that the recent rise in Islamic capital experienced by this country has contributed to the burgeoning of the Islamic consumer market. Hence, the conclusion arises that the forces of capitalism are unavoidable in the tourism sector, be it conventional tourism or halal tourism. In essence, businesses involved in the halal tourism sector provide Muslim friendly services to their clients with the goal of deriving financial benefits. As far as Muslim tourists themselves are concerned, a study by Elaziz and Kurt (2017) has found that they have a proclivity to provide excuses for their going on vacation. Elaziz and Kurt (2017) elaborate on these findings to suggest that even some religious devotees have espoused capitalist consumer culture or, in other words, a vacation of tourism culture. Overall, what these tidbits imply is that halal tourism is not necessarily a purely religious phenomenon based on religious ideology.

Regarding, there seem to be adequate grounds to assert that the halal travel sector holds a great promise for the future. This special-interest-tourism market is in its infancy at this juncture of history. Mattison's (2018) article for Euronews shows that this sector is quickly catching up with the broader industry. As a more resilient middle class is emerging in many predominantly Islamic nations, ever more pious Muslims now have the wherewithal to travel (Scott, 2010; Bikramjit, 2014). Mattison (2018) reckons that halal tourism will account for some $14 \%$ of global travel expenditure by 2022. El-Gohary, Edwards, and Eid (2017) also agree with the overall idea that halal tourism faces sanguine prospects, further adding: "The growth trajectory of Muslim tourism is expected to continue as Muslim increasingly come from fast-growing economies that include BRICS countries such as China and India” (p. 107). The rise in halal tourism is due to multiple factors. First of all, halal tourism is developing under the stewardship of the Organization of Islamic Cooperation. More specifically, the organization initiates and coordinates regional efforts in policy and 
regulation development, marketing and promotion, destination and industry growth, capacity building and so on (Agarwal, Busby \& Huang, 2017). Besides, individual states and individual companies within states make their efforts to foster halal tourism. The government of Indonesia introduced 12 Muslim friendly destinations in 2013 (Firdausi, Marantika, Firdaus \& Sajidah, 2017). All this augurs well for the halal tourism sector.

\section{Conclusion}

Recognizing the diversity of needs and seeking to uphold this diversity by providing specific services to Muslim people, representatives of the travel sector in many parts of the world are now increasingly offering travel services that are in strict conformity with Islamic teachings. This essay has confirmed the tentative hypothesis that the halal travel industry has both religious and economic underpinnings. Businesses involved in this sector aspire both to please its Muslim clients, so that these clients would feel comfortable during their vacations, and to derive large financial dividends from the promising and rapidly growing market. Besides, it is also crucial to note in conclusion that the rapid growth of halal tourism has implications for hotels, restaurants, airlines and other businesses involved in this sector. People in charge of these businesses need to be careful to take full advantage of the recent tendencies in the travel industry, thereby facilitating continuous development of halal tourism, but avoid the potential pitfalls at the same time. Accomplishing this in practice might, however, be challenging, for allegiance to halal tourism at the expense of other subcategories of tourism has the potential to create conflicts of interest. After all, the standards of halal tourism and conventional tourism are often incompatible. It remains to see how such incompatibilities will resolve in the future.

\section{References}


Adas, A. (2006). The making of entrepreneurial Islam and the Islamic spirit of capitalism. Journal for Cultural Research, 10(2), 113-125.

Agarwal, S., Busby, G., \& Huang, R. (2017). Special interest tourism: Concepts, contexts and cases. Dublin, Ireland: CABI.

Al-Hamarneh, A. (2008). Islamic tourism: A long-term strategy of tourist industries in the Arab world after 9/11. Center of Research on the Arab World. Retrieved from https://www.researchgate.net/deref/http\%3A\%2F\%2Fwww.ceraw.uni-mainz.de\%2F

Bikramjit, R. (2014). Islamic perspectives on marketing and consumer behavior: Planning, implementation, and control. New York, NY: IGI Global.

Bourgeois, N. (2016, September 14). Islamic tourism: Much more than the pilgrimage to Mecca. In Focus. Retrieved from https://infocus.wief.org/islamic-tourism-muchpilgrimage-mecca/

Demir, O., \& Toprak, M. (2004). Anatolian tigers or Islamic capital: Prospects and challenges. Middle Eastern Studies, 40(6), 166-188.

Eddahar, N. (2016). Muslim friendly tourism branding in the global market. Organization of Islamic Cooperation. Retrieved from https://www.oicoci.org/docdown/?docID=1827\&refID=1071

Elaziz, M., \& Kurt, A. (2017). Religiosity, consumerism and halal tourism: A study of seaside tourism organizations in Turkey. Tourism, 65(1), 115-128.

El-Gohary, H., Edwards, D., \& Eid, R. (2017). Global perspectives on religious tourism and pilgrimage. New York, NY: IGI Global.

Firdausi, I., Marantika, S., Firdaus, Z., \& Sajidah, R. (2017). Lombok: Halal tourism as a new Indonesia tourism strategy. $4^{\text {th }}$ Conference on Humanities, Social Sciences and Education. Retrieved from http://heaig.org/images/proceedings_pdf/H0317447.pdf

Hashim, N., Shariff, N., Mahamood, S., \& Bhari, A. (2018). Proceedings of the $3^{\text {rd }}$ 
International Halal Conference. Berlin, Germany: Springer.

Henderson, J. (2009). Islamic tourism reviewed. Tourism Recreation Research, 32(2), 207212.

Kozak, M., \& Kozak, N. (2015). Destination marketing: An international perspective. London, UK: Routledge.

Mattison, T. (2018, 9 September). How are young Muslims boosting the halal tourism industry? Euronews. Retrieved from https://www.euronews.com/2018/09/07/how-areyoung-muslims-boosting-the-halal-tourism-industry

Raj, R., \& Griffin, K. (2017). Conflicts, religion and culture in tourism. Dublin, Ireland: CABI.

Reiter, Y. (2008). Jerusalem and its role in Islamic solidarity. Berlin, Germany: Springer. Scott, N. (2010). Tourism in the Muslim world. London, UK: Emerald.

Shirazi, F. (2016). Brand Islam: The marketing and commodification of piety. Austin, TX: University of Texas Press.

Strategic roadmap for development of Islamic tourism in OIC member countries. (2017). Organization of Islamic Cooperation. Retrieved from https://www.oicoci.org/docdown/?docID=1777\&refID=1071

US Congress. (2009). Exploring the nature of Uighur nationalism. Washington, DC: US Congress. 